\title{
Memória sonora: A importância do ato de ler
}

Paulo Freire

Conferência de abertura do 30 COLE (Congresso de Leitura do Brasil) - com apresentação de Larissa de Souza Oliveira

Memory of the sound: The importance of the act of reading Paulo Freire

Keynote Presentation at the zrd Congresso de Leitura do Brasil (Conference of Reading in Brazil) - with a presentation by Larissa de Souza Oliveira

https://doi.org/10.34112/2317-0972a2021V39n83р33-50

Larissa de Souza Oliveira

[...] há três anos, quando realizamos o primeiro Congresso de Leitura [1978], nós fizemos uma mesa redonda sobre o método Paulo Freire. Naquela época, a gente não tinha o Paulo Freire aqui no Brasil (...), mas hoje a gente está repetindo com o Paulo Freire em pessoa.

Paulo, muito obrigado. Ezequiel Theodoro da Silva $3^{\circ}$ COLE, 1981

No ano do centenário do Professor Paulo Freire, a pesquisa $A L B$ : memórias ${ }^{1}$ oferece um presente para a comunidade acadêmica. Disponibilizamos a transcrição ${ }^{2}$ de A importância do ato de ler, escrito fundamental da obra do professor, realizado em circunstância da Conferência de Abertura do $3{ }^{\circ}$ Congresso de Leitura do Brasil

1. Coordenada pela Professora Doutora Lilian Lopes Martin da Silva, desde 2009, a pesquisa ALB: memórias organiza e investiga os documentos dos Congressos de Leitura do Brasil (COLE) e da entidade que os organiza, a Associação de Leitura do Brasil (ALB). Para mais informações, consultar: https://www.alleaula. fe.unicamp.br/grupos-de-pesquisas/pesquisa-alb-memorias.

2. Transcrição realizada e revisada por Larissa de Souza Oliveira (sor.larissa@gmail.com), doutoranda vinculada ao grupo de pesquisa "Alfabetização, leitura e escrita/Trabalho docente e formação inicial" (ALLEAULA) da Faculdade de Educação-Unicamp https://www.alleaula.fe.unicamp.br/ e integrante da pesquisa $A L B$ : memórias. 
(COLE) em 13 de novembro de 1981, quando também seria fundada a Associação de Leitura do Brasil (ALB), completando 40 anos.

Os arquivos dos COLEs contam um pouco da história da leitura no país, em suas mais diversas perspectivas: no que diz respeito à teoria e prática no ensino de leitura; em relação às políticas públicas, às políticas institucionais, aos livros didáticos, ao mercado editorial, ao universo literário, à formação do professor, à formação do aluno. A realização dos primeiros congressos (1978-1983) ocorre num momento histórico que apresenta mudanças consideráveis não só de cunho político, mas socioculturais para o país, em decorrência da ainda vigente ditadura militar. Parte dessa história da leitura ganha vida na voz do educador Paulo Freire, teoricamente e na prática, nas reflexões dos professores, dos profissionais do livro e da leitura, no chão de escola, nas políticas educacionais, na vida de tantos alfabetizandos do nosso país...

O professor Paulo Freire, recém-chegado ao Brasil do exílio, que durou 16 anos, abre $\mathrm{o} 3^{\circ}$ COLE com a apresentação do texto $A$ importância do ato de ler. Trata-se um texto híbrido, que não é um texto autobiográfico essencialmente, mas traz memórias do professor de quando se formava leitor, no processo de compreender seu mundo, e de quando atuava (e se formava) enquanto professor - formando outros leitores. É um texto que apresenta pensamentos teóricos e práticos sobre a leitura, $\mathrm{o}$ ato de ler, estando no polo da produção de conhecimento, da mesma forma em que se insere no polo da reflexão. Em seu texto, Freire afirma:

É como se eu estivesse agora fazendo a "arqueologia" de minha compreensão do complexo ato de ler, ao longo de minha experiência existencial. Daí que tenha falado de momentos de minha infância, de minha adolescência, dos começos de minha mocidade e termine agora revendo, em traços gerais, alguns dos aspectos centrais da proposta que fiz no campo da alfabetização de adultos, há alguns anos passados. (FREIRE, 1981, p. 05).

Em 1982, Paulo Freire reúne este texto e outros dois: Alfabetização de adultos e bibliotecas populares - uma introdução, que também é uma fala de Freire em Congresso, o XI Congresso Brasileiro de Biblioteconomia e Documentação, realizado em João Pessoa em janeiro de 1982 (FREIRE, 1982, p. 14); e $O$ povo diz a sua palavra a sua alfabetização em São Tomée Príncipe, um artigo "que foi primeiramente publicado num número especial da Harvard Educational Review, em fevereiro de 1981, número que tratou do tema Education as Transformation: Identity, Change and Development" ao qual Freire se refere no $3^{\circ}$ COLE, "acrescido de uma segunda parte" (FREIRE, 1982, p. 15). Apresentando o 
livro, Paulo Freire diz que "os três textos que aparecem no livro têm que ver um com o outro, na sua temática” (FREIRE, 1982, p. 8). Com o título A importância do ato de ler: em três artigos que se completam, este pequeno livro foi impresso muitas vezes no Brasil e no mundo, inclusive, "mereceu, em julho de 1990, o “Diploma de Mérito Internacional”, concedido pela "International Reading Association", na Suécia”.

A transcrição que apresentamos agora está organizada de forma intercalada entre o texto originalmente publicado nos Resumos do $3^{\circ} \mathrm{COLE}$, a partir de um manuscrito do autor ${ }^{4}$ entregue aos organizadores para a composição dos Anais, e trechos de sua exposição oral, destacados em itálico, que não foram publicados ${ }^{5}$. Falas espontâneas de Freire, aquelas que não estavam previstas inicialmente por ele na escritura do texto que lhe serviu de base para a conferência.

\section{Conferência de Abertura do $3^{\circ}$ COlE \\ A importância do ATO DE LER - PAUlo Freire}

Em primeiro lugar, além de uma certa especial alegria que eu tenho de estar aqui precisamente pela sensibilidade que o problema da leitura sempre me provocou, desde faz muito tempo, eu quero também dizer da satisfação de me encontrar nesta manhã com professores e professoras do país. Mas apenas eu preciso pedir desculpas antecipadamente pelo fato de que, terminando de fazer uma coisa raríssima na minha vida que é ler um texto, eu sempre escrevo textos que viram livros, mas nunca leio os textos assim para todos. Terminada a leitura possivelmente eu fico cinco minutos no máximo, que é tempo suficiente pra sair, porque eu tenho que voltar imediatamente pra São Paulo. Eu tenho amanhã um compromisso em Belo Horizonte para o qual eu tenho uma série de coisas a acertar e na volta eu tenho outro que precisa também ser preparado e, lamentavelmente, eu sinto inclusive profundamente não poder participar do encontro em toda sua extensão porque a temática desse encontro me parece assim... me toca intensamente. Mas a gente faz o que pode e não o que a gente gostaria de fazer. Então de fato a minha presença aqui assim não é formal, mas realmente é de uma abertura ou de uma semiabertura, eu tenho até

3. Informação extraída do site "Projeto Memória”. Disponível em: http://www.projetomemoria.art.br/ PauloFreire/biografia/o7_biografia_cronologia.html. Acesso em: 25 fev. 2021.

4. Por esse motivo, as aspas presentes no texto original foram mantidas nesta transcrição. A escrita gráfica de algumas palavras, porém, foi adequada ao Novo Acordo Ortográfico da Língua Portuguesa.

5. Alguns trechos em itálicos foram destacados também com sublinhado para identificar alguma marca sonora ou registrar alguma ação que não se trata de falas do autor. [Nota da transcrição] 
medo de usar essa palavra sem que eu seja punido já já. Agora a Unicamp acreditou nessa história e está sendo punida severamente. Então outra coisa que eu agora diria tambémé o seguinte: eu escrevi aqui algumas páginas no tempo que fui dispondo e inventando pra mim e sem ter muito tempo desde o momento em que o Ezequiel me colocou, e de uma maneira muito compreensiva, porque ele já admitia ao colocar a possibilidade de que eu não pudesse vir, mas eu aceitei imediatamente, mas vocês imaginam que eu terminei as últimas palavrinhas deste pequeno texto que eu vou ler à 1 h3omin de hoje, da manhã de hoje. Isso foi o tempo que eu dispus e é possivel que de vez em quando até eu pare, saia do texto e comente ou então o estenda um pouco, mas estou certíssimo de que às 1oh vocês têm que estar já numa sessão outra de trabalho, então eu respeitarei muito o interesse de vocês. Agora eu vou tentar fazer uma leitura nada burocrática de um texto. Eu vou tentar ler tão dinamicamente quanto eu acho que eu escrevo.

Começaria dizendo exatamente que rara tem sido a vez, ao longo de tantos anos de uma prática pedagógica, por isso mesmo uma prática política, em que me tenho permitido a tarefa de abrir, de inaugurar ou de encerrar encontros ou congressos. Eu tenho a impressão, e agora já saí do texto, eu tenho impressão de que na verdade esta éa primeira que eu faço isso, a nivel de mundo. Quando me convidam pra abrir congressos fora do Brasil eu sempre digo que não, não sei... eu não tenho charme para essas coisas.

Aceitei fazê-lo agora da maneira, porém, menos formal possível. Aceitei vir aqui para falar um pouco da importância do hábito de ler.

Me parece indispensável, ao procurar falar de tal importância, dizer algo do momento mesmo em que me preparava para aqui estar agora; dizer algo do processo em que fui me inserindo enquanto ia escrevendo este texto que agora leio, processo que envolvia uma compreensão crítica do ato de ler, que não se esgota na descodificação pura da palavra escrita ou da linguagem escrita, mas que se antecipa e se alonga na inteligência do mundo. A leitura do mundo precede a leitura da palavra, daí que a posterior leitura da palavra não possa prescindir da continuidade da leitura do mundo. Linguagem e realidade se prendem dialeticamente. A compreensão do texto a ser alcançada por sua leitura crítica implica na percepção das relações entre o texto e o contexto.

Ao ensaiar escrever o texto que trata sobre a importância do ato de ler, eu me senti levado - e até gostosamente - a "reler" momentos fundamentais de minha prática, guardados na memória, desde as experiências mais remotas de minha infância, de minha adolescência, de minha mocidade, em que a compreensão crítica da importância do ato de ler se veio em mim constituindo. 
Eu gostaria agora de sair um pouquinho do texto escrito. Em lugar de, por exemplo, tomar a compreensão, a importância da leitura, do ato de ler, que foi o tema que me propuseram, em lugar de tomar isso de um ponto de vista, por exemplo, linguístico, psicolinguístico, pedagógico. Em lugar de me emaranhar, por exemplo, numa série de reflexões em torno de certas teorias em torno da leitura. Em lugar de ficar ou com os semanticistas ou com os sintaxistas para a compreensão do texto, eu não fico nem com um, nem com outro, apenas. Me pareceu muito melhor, a mim, pelo menos, refletir sobre como em mim se vem constituindo historicamente a minh a compreensão da necessidade da leitura. Eu espero que não fruste vocês porque eu não falo desses autores todos, desses especialistas, mas eu falo da minha prática e como nela se veio constituindo a minha compreensão crítica da importância do ato de ler.

Ao ir escrevendo este texto, ia "tomando distância" dos diferentes momentos em que o ato de ler se veio dando na minha experiência existencial. Primeiro, a "leitura" do mundo, do pequeno mundo em que me movia; depois, a leitura da palavra que nem sempre, ao longo de minha escolarização, foi a leitura da "palavramundo". Não é a leitura da palavra "mundo", mas a leitura da "palavramundo", uma palavra só.

A retomada da infância distante, e agora, me carece dizer, lamentavelmente distante, buscando a compreensão do meu ato de "ler" o mundo particular em que me movia - e até onde não sou traído pela memória -, me é absolutamente significativa. Neste esforço a que me vou entregando, recrio, e revivo, no texto que escrevo, a experiência vivida no momento em que ainda não lia a palavra. Me vejo então na casa mediana em que nasci, no Recife, rodeada de árvores, algumas delas como se fossem gente, tal a intimidade entre nós - à sua sombra brincava e em seus galhos mais dóceis à minha altura eu me experimentava em riscos menores que me preparavam para riscos e aventuras maiores.

A velha casa, seus quartos, seu corredor, seu sótão, seu terraço - o sítio das avencas de minha mãe -, o quintal amplo em que se achava, tudo isso foi o meu primeiro mundo. Nele engatinhei, balbuciei, me pus de pé, andei, falei. Na verdade, aquele mundo especial se dava a mim como o mundo de minha atividade perceptiva, por isso mesmo como o mundo de minhas primeiras leituras. Os "textos", com aspas, as "palavras", as "letras" daquele contexto - em cuja percepção me experimentava e, quanto mais o fazia, mais aumentava a capacidade de perceber - se encarnavam numa série de coisas, de objetos, de sinais, cuja compreensão eu ia apreendendo no meu trato com eles nas minhas relações com meus irmãos mais velhos e com meus pais. 
Os "textos", as "palavras", as "letras" daquele contexto se encarnavam no canto dos pássaros - o do sanhaçu, o do olha-pro-caminho-quem-vem, o do bem-te-vi, o do sabiá; na dança das copas das árvores sopradas por fortes ventanias que anunciavam tempestades, trovões, relâmpagos; as águas da chuva brincando de geografia: inventando lagos, ilhas, rios, riachos no quintal de minha casa. Os "textos", as "palavras", as "letras" daquele contexto se encarnavam também no assobio do vento, nas nuvens do céu, nas suas cores, nos seus movimentos; na cor das folhagens, na forma das folhas, no cheiro das flores - das rosas, dos jasmins -, no corpo das árvores, na casca dos frutos. Na tonalidade diferente de cores de um mesmo fruto em momentos distintos: o verde da manga-espada verde, o verde da manga-espada inchada; o amarelo esverdeado da mesma manga amadurecendo, as pintas negras da manga mais além de madura. A relação entre estas cores, o desenvolvimento do fruto, a sua resistência à nossa manipulação e o seu gosto. Foi nesse tempo, possivelmente, que eu, fazendo e vendo fazer, aprendi a significação da ação de amolegar.

Ainda hoje eu amolego as mangas para chupá-las, eu não corto para comê-las em fatias. Dificilmente um menino do Nordeste estraga uma manga espada desse jeito. E é interessante porque vocês não sabem a emoção que eu tive quando vi outros meninos, outros Paulos, pretos, na África, amolegando mangas como eu. Poxa, meu tempo de exílio era, de vez em quando, tempo de encontro e reencontro com nosso país, por isso um tempo de prazer também, não só de tristeza.

Daquele contexto, quer dizer, daquele primeiro mundo meu, faziam parte igualmente os animais: os gatos da família, a sua maneira manhosa de enroscar-se nas pernas da gente, o seu miado, de súplica ou de raiva; Joli, o velho cachorro negro de meu pai, o seu mau humor toda vez que um dos gatos incautamente se aproximava demasiado do sítio em que se achava comendo e que era seu, ele tinha direito de propriedade sobre aquilo, "estado de espírito", o de Joli, nestas ocasiões, completamente diferente do de quando quase desportivamente perseguia, acuava e matava um dos muitos timbus, não sei se vocês conhecem esse bichinho, esse animal, responsáveis pelo sumiço de gordas galinhas de minha avó.

Daquele contexto - o do meu mundo imediato - fazia parte, por outro lado, o universo da linguagem dos mais velhos, expressando as suas crenças, os seus gostos, os seus receios, os seus valores. Tudo isso ligado a contextos mais amplos que o do meu mundo imediato e de cuja existência eu não podia sequer suspeitar.

No esforço de retomar a infância distante, a que já me referi, buscando a compreensão do meu ato de ler o mundo particular em que me movia, permitam-me 
repetir, recrio, revivo, no texto que escrevo, a experiência vivida no momento em que ainda não lia a palavra. E algo que me parece importante, no contexto geral de que venho falando, emerge agora insinuando a sua presença no corpo destas reflexões. $\mathrm{Me}$ refiro a meu medo das almas penadas cuja presença entre nós era permanente objeto das conversas dos mais velhos, no tempo de minha infância. Havia um outro tema, que era fundamental, que era o tema das doenças. Há um pouco de necrofilia misturada com um muito de biofilia na cultura brasileira, esse certo gosto da morte, do parado. Não se pode ver um desastre que não se sinta mais ou menos impelido para olhar, nem que seja de longe, um corpo estragado. Eu me lembro que se falava muito dessa coisa da aproximação da morte. As almas penadas precisavam da escuridão ou da semiescuridão para aparecer, das formas mais diversas - ora gemendo a dor de suas culpas, ora gargalhando zombeteiramente, ora pedindo orações ou indicando esconderijos de botijas. Ora, até possivelmente os meus sete anos, o bairro do Recite onde nasci era iluminado por lampiões que se perfilavam, com certa dignidade, pelas ruas. Lampiões elegantes que, ao cair da noite, se entregavam à vara mágica de seus acendedores. Eu costumava acompanhar, do portão de minha casa, de longe, a figura magra do acendedor de lampiões de minha rua, que vinha vindo, andar ritmado, vara iluminadora ao ombro, de lampião a lampião, dando luz à rua. Uma luz precária, mais precária do que a que tínhamos dentro de casa. Uma luz muito mais tomada pelas sombras do que iluminadora delas.

Não havia melhor clima para peraltices das almas do que aquele. Me lembro das noites em que, envolvido no meu medo, esperava que o tempo passasse, que a noite se fosse, que a madrugada semiclareada viesse trazendo com ela o canto dos passarinhos "manhecedores".

Os meus temores noturnos terminaram por me aguçar, nas manhãs abertas, a percepção de um sem-número de ruídos que se perdiam na claridade e na algazarra dos dias e que eram misteriosamente sublinhados no silêncio fundo das noites.

Na medida, porém, em que me fui tornando íntimo do meu mundo, em que melhor o percebia e o entendia na leitura que dele ia fazendo, os meus temores iam diminuindo.

Eu nunca esqueço, afinal de contas é engraçado isso, o meu quarto de dormir e a minha cama, em tenra idade, se constituíram como o meu primeiro contexto teórico em que eu tomava distância do contexto concreto que era o quintal da casa, que era o mundo particular meu, em que eu pensava sobre ele. Era engraçado, ao mesmo tempo em que eu estava agasalhado pelo medo, eu me lembro, por exemplo, do relógio grande, que acho que muita gente que está aqui ainda tem na casa dos avós, este relógio que faz tic-tac-tic-tac, um carrilhão que nas horas ele bate, sete pancadas ou oito, três. Eu me lembro de um silêncio 
imenso da noite, o medo quase tão grande quanto o silêncio. Eu me lembro de uma certa camaradagem que eu estabeleci e era uma forma de ler aquele silêncio, de ler o medo, interpretar o medo. Eu me lembro de como, por exemplo, eu estabeleci uma relação afetiva e necessária com o relógio e como e por quê. É que o relógio, no silêncio inteiro da casa, propício às peraltices das almas, o relógio era a única presença viva para mim, no tic-tac dele. Então me lembro que eu me tomava assim de uma camaradagem necessária com o relógio, no fundo o relógio me ajudava a esperar que a noite se fosse. E aí eu pensava também no dia de amanhã, na brincadeira que eu fazia, nos brinquedos. E quando era de manhã, por exemplo, eu transformava também, porque no fundo o contexto teórico é prático e o contexto prático é teórico. De manhã no meu contexto prático, concreto, objetivo em que eu brincava... não sei se as pernambucanas e os pernambucanos que estão aqui se lembram, não sei se existe ainda uma coisa que se chamava lá na minha infância "caroline", que era uma árvore que dá uns frutos que não se comem, umas sementes grandes, que eu brincava com meus irmãos de transformar essas sementes grandes como se fossem maiores do que um fruta-pão, do mesmo tamanho do fruta-pão, mas em forma distinta, como se fosse uma cápsula de cacau grande. Eu me lembro que eu punha uns pés nessa cápsula chamada de caroline com um pedaço de pau e transformava isso tudo em bois, em cavalos, e fazíamos um cercado etc. No fundo era uma leitura do meu mundo e uma escrita desse meu mundo também, na medida em que eu transformava as coisas e eu me lembro que aí, pensando no medo das noites, eu aguçava a capacidade perceptiva aos dias, a compreensão dos ruídos. É engraçado, prestem atenção que sob a luz do sol, há uma infinidade de ruídos que se perdem, que passam despercebidos a nós, mas que na noite silenciosa, sem eletricidade, tempo bom pra alma, certos ruídos que de manhã passam despercebidos são sublinhados, intensamente na noite. Então vocês não imaginam a alegria que eu tive no dia que eu vi a razão de ser de um certo gemido, um ruído que era como se fosse um gemido, que não era outra coisa senão um galho repousando sobre outro. $O$ vento soprava e o galho roçava no outro e roçando no outro provocava um gemido que de noite dava certinho com alma. Então o que acontece, quanto mais eu lia esse meu mundo, quanto mais eu ia decifrando esse mundo, eu ia percebendo esse mundo, tanto mais eu me libertava das apreensões noturnas. É uma coisa interessante, eu não quero ser aqui psicologista, que é uma coisa que eu detesto, acho ridícula e errada cientificamente. Psicólogo sim, acho que é formidável, mas não sou, mas sou e não sou, mas todo mundo é. Mas eu acho que tem certos pedaços... não é por acaso que inclusive estou escrevendo um livro agora, vendo se termino, em que eu tomo tudo isso, me vejo de novo porque eu acho que tem muito pedaço realmente da minha experiência de infância que tem muito que ver diretamente com o homem de sessenta anos que sou hoje, 
mas que conservou o menino de sete dentro dele. Isso é uma coisa que eu vou morrer com o danadinho do menino, vou morrer dois Paulos que estão integrados a vida inteira no percurso todo da minha vida. Eu até sou três porque um é o menino que eu fui, outro é um menino que eu não pude ser e o outro é o homem que estou sendo. Esses três dialeticamente se cumprimentam diariamente, se encontram. Eu não tenho dúvida nenhuma que qualquer dicotomia entre eles não me possibilita nem a mim mesmo me entender. É por isso que tem muita gente que vive escrevendo sobre mim e dá uns "fora louco". Mas deixe-me voltar. Isso é uma coisa que eu espero que eu não esteja muito fora do tema, eu me acho profundamente dentro do tema. Pra mim, isso que estou dizendo aqui, isso que eu fiz é a leitura mesmo. Bem, mas volto ao período anterior que havia lido. [Relê o período anterior. Na medida, porém, em que me fui tornando íntimo do meu mundo, em que melhor o percebia e o entendia na leitura que dele ia fazendo, os meus temores iam diminuindo.]

Mas, é importante dizer, a leitura do meu mundo, que me foi sempre fundamental, não fez de mim um menino antecipado em homem, um racionalista de calças curtas. O que teria sido? Você já imaginou um menino de sete anos, oito, dez, cartesiano? É um desastre. Terrível. Um menino de oito, dez anos, onze, que é o tempo em que eu vivi tudo isso, um processo demorado, formador. Mas um menino dessa idade de colarinho duro, gravata preta, empertigado, fazendo discursos... teria sido um desastre isso. Não, o que eu digo aqui é realmente a verdade. A curiosidade do menino não iria distorcer-se pelo simples fato de ser exercida, no que fui mais ajudado do que desajudado por meus pais. Olha, eu não tenho dúvida nenhuma, do que sem cair em um tipo de racionalismo, no fundo vira irracionalismo. $O$ estímulo, o desafio vira melhor. $O$ desafio, a curiosidade com que a criança se faz é absolutamente fundamental ao próprio processo da leitura. $O$ desenvolvimento, o desafio, a expressividade oral na criança. $O$ desafio à continuidade da leitura do seu mundo, concomitantemente com a leitura da palavra é absolutamente indispensável a quem trabalha com leitura, com criança. Eé interessante, eu não preciso de ler nenhum especialista, por isso que eu preferi esse procedimento agora, ao apresentar este trabalho a vocês. É que, no fundo, é lógico que eu leio os especialistas, eu estudo os especialistas, mesmo sem ser eu um especialista nisso, enquanto um educador eu não posso estar ausente de uma problemática como essa, mas sobretudo o que os especialistas às vezes me ajudam e às vezes não compreendem nos seus livros é exatamente o que eu tentei compreender em mim mesmo, quer dizer, isso é uma coisa de que eu nunca escapo, eu penso muito a prática no que eu participo porque para mim é a única maneira de pensar certo, é pensar a prática. Então esse problema da curiosidade, do atendimento a ela. Eu me lembro, por exemplo, de que jamais estando 
em casa, com quem quer que fosse, conversando no terraço, daqueles terraços do Recife, mesmo nos domingos, que são sempre soprados por aquele ventinho ensinado. Eu me lembro de que jamais, estando conversando com alguém, fosse o reitor da universidade, o pároco da freguesia, não importa quem, ou um professor estrangeiro, jamais um dos filhos ou uma das filhas que chegasse a mim correndo e parasse em cima das minhas pernas, numa espécie assim de freio de ar [som de freio de ar] e dissesse "papai, o que é isso?"- às vezes era uma dúvida que surgia no papo entre eles, na brincadeira entre eles, então corria para a fonte. Lá os pais são sempre, em certo momento da vida, fonte. São ídolos e depois podem ser também decepção. - e eu me lembro de que eu parava o que eu estava dizendo ou que eu estava dizendo ou que eu estava ouvindo, dizia para a pessoa "olha, com licença, um momento" e atendia à solicitação ou eu dizia que sabia ou eu dizia que não sabia, mas que depois eu ia procurar saber com ele ou com ela. Mas uma coisa eu jamais fiz foi abortar um processo de curiosidade, que faz parte daquele primeiro momento em que o ato da leitura é a leitura do mundo, é a leitura do real, é a leitura do concreto para poder depois ser a leitura, ou começar a ser a leitura da palavra. Quer dizer, há muita gente profundamente que está iludida quando pensa que uma criança que vai se alfabetizar não lê. Ela não lê a palavra, mas ela lê o mundo já. E então seu processo da sua alfabetização se dará na medida em que essa leitura agora da palavra se insira na leitura do mundo e continue a estimular a continuidade da leitura do mundo. Muito bem, então eu repito aqui: A curiosidade do menino não iria distorcer-se pelo simples fato de ser exercida, no que fui mais ajudado do que desajudado por meus pais. E foi com eles, precisamente, em certo momento dessa rica experiência de compreensão do meu mundo imediato, sem que tal compreensão tivesse significado malquerenças ao que ele tinha de encantadoramente misterioso, que eu comecei a ser introduzido na leitura da palavra. Eu insisti aqui em dizer que, em certo sentido estou enfatizando uma afirmação anterior, e isso é muito comum, ir e voltar, ir e voltar, ao mesmo tempo, eu enfatizei aqui que a minha curiosidade, a minha busca, minha tentativa de percepção do mundo não significou jamais nenhum tipo de malquerença que eu tivesse tido com o que havia de encantadoramente misterioso no meu mundo, o que teria sido então, realmente, um desastre. Aí seria eu cartesiano, com sete anos, com dez anos. E foi então nesse pequeno mundo, e essa coisa de meus pais é uma coisa que me marcou intensamente como educador hoje, que me marca. Quer dizer, eu fui alfabetizado por eles, no quintal da minha casa, que por sinal ainda está de pé e eu estou absolutamente convencido, e depois consegui saber que há um litígio com relação à casa onde eu nasci e é por isso que ela continua lá na Estrada do Encanamento, 724, cheia com as mesmas árvores, porque 
não deu para derrubarem e fazerem um baita de um edifício. Só assim se explicava eu ter passado 16 anos no exilio depois que eu nasci por lá e voltasse e encontrasse a mesma casa por lá. Fui lá e vou toda vez. Se eu pudesse, eu arranjava um jeito era de entrar nesse litígio para comprar a casa pra mim e passar as férias lá. Mas não dá, quer dizer, um professor que estuda a leitura e a pedagogia não pode comprar casa assim. Mas bem, então eu digo, pois foi com eles necessariamente, precisamente, que eu fui introduzido na leitura da palavra. A decifração da palavra fluía naturalmente da "leitura" do meu mundo particular. Ela vinha, ela vinha do mundo mesmo, ela vinha do chão. Não era algo, essa leitura da palavra não era algo que se estivesse dando superpostamente a ele ou distante dele, estrangeiramente a ele. Fui alfabetizado no chão do quintal de minha casa, à sombra das mangueiras, com palavras do meu mundo e não do mundo maior dos meus pais. $\mathrm{O}$ chão foi o meu quadro-negro; gravetos, o meu giz.

Por isso é que, ao chegar à escolinha particular de Eunice Vasconcelos, cujo desaparecimento recente me feriu e me doeu, e a quem presto agora uma homenagem sentida, já estava alfabetizado. Eunice continuou e aprofundou o trabalho de meus pais. Com ela, a leitura da palavra, da frase, da sentença, jamais significou uma ruptura com a "leitura" do mundo. Com ela, a leitura da palavra foi a leitura da "palavramundo".

Há pouco tempo, com emoção relativamente profunda, visitei a casa onde nasci. Pisei o mesmo chão em que me pus de pé, andei, corri, falei e aprendi a ler. O mesmo mundo, primeiro mundo que se deu à minha compreensão pela "leitura" que dele fui fazendo. Lá, reencontrei algumas das árvores da minha infância. Reconheci-as sem dificuldade. Quase abracei os grossos troncos, os jovens troncos de minha infância. Então, uma saudade que eu costumo chamar, desde o exílio, de mansa ou de bem-comportada saindo do chão, das árvores, da casa, me envolveu cuidadosamente. Deixei a casa contente, com a alegria de quem reencontra gente querida.

Continuando neste esforço de "reler" momentos fundamentais de experiências de minha infância, de minha adolescência, de minha mocidade, em que a compreensão crítica da importância do ato de ler se veio em mim constituindo através de sua prática, retomo o tempo em que, como aluno do chamado curso ginasial, hoje não se chama isso mais não, me experimentei na percepção crítica dos textos que lia em classe, com a colaboração, até hoje recordada, do meu então professor de língua portuguesa. Não sei se esse professor meu da época, que era muito moço inclusive, é hoje vivo, o que faz pelo Recife. Mas uma coisa eu sei é que ele, e agora eu usaria uma sintaxe bem povo, ele influenciou comigo e eu me tornei também professor de português. Veja, eu citei agora essa regência do verbo influenciar porque semana passada eu li, durante 
três horas, textos de homens do nordeste, de mulheres do nordeste em São Paulo, textos que se vão constituir em livros deles. E lá eu encontrei a regência, essa sintaxe do verbo influenciar, influenciar com, por isso que me lembrei agora de citar, por trás da qual, no fundo, há toda uma concepção do mundo. Veja como esse problema da leitura da leitura, da leitura da escrita, sem a compreensão do contexto não tem sentido. Quer dizer, a compreensão da sintaxe que está lá. Não há dúvida nenhuma que, se você faz uma análise de texto, no sentido de uma penetração do texto e no texto, essa regência verbal sugere a nós, pelo menos, que do ponto de vista político, este homem do nordeste tem uma concepção profundamente democrática, não do ponto de vista burguês. O influir com, no fundo, é a coparticipação de sujeitos cognoscentes no processo de conhecer e não há leitura verdadeira que não seja isso. Daqui a pouco eu acho que toco um pouquinho nessa história. Mas esse professor meu, da minha adolescência... eu comecei a estudar muito mais velho do que todos que estão aqui, não tenho nem dúvida, eu tinha 16 anos quando eu fiz o exame de admissão e naquele tempo se fazia com 10 e 11, e hoje também, vocês vejam que eu às vezes fico com uma pena tremenda de filhos, de pais que vivem com a chamada angústia da genialidade dos filhos que deve ser apreendida pela escolarização. Minha nossa senhora. Em São Paulo, por exemplo, não sei se no Recife está assim já, mas eu São Paulo está fazendo vestibularzinho para crianças de quatro anos. Veja que coisa maravilhosa, como testemunho de destruição do ser. Então o que eu sempre digo a pais nervosos, inquietos, é que eu, aos 16 anos escrevia, rato com dois erres. Eu nunca esqueço porque eu escrevi uma carta para minha mãe e botei... eu achava profundamente lógico um danado de um " $r$ " forte como esse rato, como é que não é com dois? Então eu metia os dois erres e minha velhinha que já morreu e a "Abertura" não deu tempo de eu revê-la, um ano e meio antes da chamada "Abertura" ela se foi. Mas me lembro que a velhinha me respondeu ainda, quando muito moça: "meu filhinho, rato se escreve com um erre só". Mas eu tinha 16 anos quando escrevia rato com um erre só e estava no primeiro ano do ginásio e os colegas da minha geração cujos pais tinham poder suficiente, aquisitivo, estavam no começo das faculdades. Pois, se vocês me perguntam "Paulo, será que tu perdeste tempo?”, eu acho que minha própria prática mostrou que eu não perdi. Quer dizer, eu ganhei um tempo maravilhoso, enquanto não era estragado pela escola, eu lia o mundo bem, então eu não perdi tempo. Espero que nesse congresso não haja nenhum pai, nenhuma mãe angustiado por causa da escolaridade dos filhos, se houver, tome aqui o velho Paulo como exemplo. Naquela época, por exemplo, se tivesse chegado ao Brasil, eu digo muito isso nos Estados Unidos, vivo dando seminário por lá, algum psicólogo branco, que eu costumo chamar de psicologia branca, white psychology, tivesse vindo ao 
Brasil aplicar uma bateria de testes em mim, possivelmente teria concluído que eu era geneticamente incapaz. Mas bem, então voltando a esse negócio desse professor que me marcou muito... meu deus do céu, vou acelerar [recomeça a ler o texto apressadamente... se veio em mim constituindo através de sua prática, retomo o tempo em que, como aluno do chamado curso ginasial, me experimentei [estou procurando exatamente onde parei] na percepção crítica dos textos que lia em classe, com a colaboração, até hoje recordada, do meu então professor de língua portuguesa.]

Não eram, porém, aqueles momentos puros exercícios de que resultasse um simples dar-nos conta a existência de uma página escrita diante de nós que devesse ser cadenciada, mecânica e enfadonhamente "soletrada" em vez de realmente lida. Não eram aqueles momentos "lições de leitura", no sentido tradicional desta expressão. Eram momentos em que os textos se davam à nossa inquieta procura, incluindo a do então jovem professor José Pessoa.

Algum tempo depois, como professor também de português, nos meus quase vinte anos, vivi intensamente a importância do ato de ler e de escrever, no fundo indicotomizáveis, com alunos das primeiras séries do então chamado curso ginasial. A regência verbal, a sintaxe de concordância, o problema da crase, nada disso era reduzido por mim a tabletes de conhecimentos que devessem ser engolidos pelos estudantes. Tudo isso, pelo contrário, era proposto à curiosidade dos alunos de maneira dinâmica e viva, no corpo mesmo de textos, ora de autores que estudávamos, ora deles próprios, como objetos a serem desvelados e não como algo parado, cujo perfil eu descrevesse. Os alunos não tinham que memorizar mecanicamente a descrição do objeto, mas apreender a sua significação profunda. Só apreendendo-a seriam capazes de saber, por isso, de memorizá-la e de fixá-la. A memorização mecânica da descrição do objeto não se constitui em conhecimento do objeto. Eu acho que isso aí, me perdoe que já são dez horas, mas para mim isso é um ponto fundamental na teoria do conhecimento e na compreensão epistemológica do que é memória. Quer dizer, o problema da memorização, só existe memorização quando há conhecimento, $e$ não ao contrário, quer dizer, então não é o esforço de recitar mecanicamente o perfil que o professor faz do objeto que leva o educando a saber. E é por isso que o estudante que faz isso, faz só a prova e no dia seguinte não sabe mais a prova que ele escreveu ontem. $́$ porque só se memoriza quando se sabe. Eu digo isto aqui agora porque eu sei isto, e não porque eu memorizei isto. Ou eu memorizei porque sei. Isso tem muito que ver com o problema da leitura, no meu entender, e da compreensão crítica do ato de ler. A memorização mecânica da descrição do objeto não se constitui em conhecimento do objeto. 
Por isso, é que a leitura de um texto, tomado como pura descrição de um objeto é feita no sentido de memorizá-la, a leitura, a descrição, nem é real leitura, nem dela, portanto, resulta o conhecimento do objeto do que o texto fala.

Creio que muito de nossa insistência, eu agora não comento mais nada e vou direto, enquanto professores e professoras, em que os estudantes "leiam", com aspas, num semestre, um sem-número de capítulos de livros, reside na compreensão errônea que às vezes temos do ato de ler. Em minha andarilhagem pelo mundo, não foram poucas as vezes em que jovens estudantes me falaram de sua luta às voltas com extensas bibliografias a serem muito mais "devoradas" do que realmente lidas ou estudadas. Verdadeiras "lições de leitura" no sentido mais tradicional desta expressão, a que se achavam submetidos em nome de sua formação científica, $e$ isso é que é trágico, e de que deviam prestar contas através do famoso controle de leitura, que no fundo é o controle do aluno. Em algumas vezes cheguei mesmo a ler, em relações bibliográficas, indicações em torno de que páginas deste ou daquele capítulo de tal ou qual livro deveriam ser lidas. Por exemplo: "Da página 15 à página 37 do Capítulo Terceiro"... Poxa que diabo, por quê? Por que da página 15? Por que não da 12? Por que não a sugestão do livro como uma totalidade? Por que não a discussão do seu conteúdo? Por que não o debate em torno da percepção total do livro? Por que não a conversa sobre o condicionamento histórico, sociológico, ideológico, político do autor do livro? Por que não situá-lo historicamente no seu contexto para que se possa entender o seu texto? É por isso que tem muita gente por aí lendo Lenine "O que fazer?" como se ele tivesse escrito em Caruaru, no ano passado. E não foi, que me conste, não. Voltando...

A insistência na quantidade de leituras sem o devido adentramento nos textos a serem compreendidos, e não mecanicamente memorizados, revela uma visão mágica da palavra escrita. Visão que urge ser superada. A mesma, ainda que encarnada desde outro ângulo, que se encontra, por exemplo, em quem escreve, quando identifica a possível qualidade de seu trabalho, ou não, com a quantidade de páginas escritas. É incrível, ou escreve uma tese de trezentas páginas ou não presta. Agora, das trezentas, duzentas e cinquenta são repetições das cinquentas fundamentais. Entende? Não tem sentido. Não tem sentido um treco desse. Se vocês me desculpem a falta de modéstia, no começo desse ano a Harvard Educational Review, que no fundo é uma revista... poxa, me pede um artigo para um número especial sobre o problema de alfabetização do Terceiro Mundo, então tinha uns cobras escrevendo para esse número. $E$ eu aceitei e escrevi o artigo. E o artigo era menor do que este texto que estou lendo. Ele tinha oito folhinhas, dez. Eu termino, mando. E agora que eu peço desculpas mesmo 
para não parecer... Afinal de contas não sou falso modesto porque é a melhor maneira de ser imodesto. Então eu mando esse treco e depois de uns oito dias, ou dez eu recebo um telefonema do corpo de editores da revista, em São Paulo, ele me telefona obviamente de Harvard me dizendo "Professor Freire [com sotaque do inglês americano] nós acabamos de ler o seu artigo e não nos contivemos e por isso estamos telefonando para dizer do quanto nos agradou a originalidade do seu texto. Tem oito folhas dessa, saiu na revista por duas e meia. Poxa... Eu não tenho esse tabu. Eu não sou mágico, entende? Imagine vocês a surra que eu ia dar em vocês e em mim mesmo se eu fosse escrever quarenta folhas para ler aqui hoje. É um desrespeito, inclusive. Acho que com essas estou dizendo o que eu quero dizer, pelo menos o que eu posso dizer, é isso. Mais do que isso era.... mas bem. [retoma leitura: A mesma, ainda que encarnada desde outro ângulo, que se encontra, por exemplo, em quem escreve, quando identifica a possível qualidade de seu trabalho, ou não, com a quantidade de páginas escritas] No entanto, um dos documentos filosóficos mais importantes de que dispomos, ainda hoje - As teses sobre Feuerbach, de Marx - tem apenas duas páginas e meia... E esse é um texto considerado, na história da Filosofia, como um dos mais fundamentais escritos até hoje. Mesmo quando o cara não aceita a posição de Marx, o que não pode é negar a importância dessas duas páginas e meia na história do pensamento.

Dentro ainda do momento bastante rico de minha experiência como professor de língua portuguesa, me lembro, tão vivamente quanto se ela fosse de agora e não de um ontem bem remoto, das vezes em que demorava na análise de textos de Gilberto Freyre, de Lins do Rego, de Graciliano Ramos, de Jorge Amado. Textos que eu levava de casa e que ia lendo com os estudantes, sublinhando aspectos de sua sintaxe, quer dizer, deles, dos autores, estreitamente ligadas ao bom gosto de sua linguagem. Àquelas análises juntava comentários em torno de necessárias diferenças entre o português de Portugal e o português do Brasil.

Venho tentando deixar claro, neste trabalho em torno da importância do ato de ler - e não é demasiado repetir agora -, que meu esforço fundamental vem sendo o de explicitar como, em mim, aquela importância vem sendo destacada. Vocês acham que eu só tenho uma folha e meia, eu posso terminar né? É como se eu estivesse agora fazendo a "arqueologia" de minha compreensão do complexo ato de ler, ao longo de minha experiência existencial. Daí que tenha falado de momentos de minha infância, de minha adolescência, dos começos de minha mocidade e termine agora revendo, em traços gerais, alguns dos aspectos centrais da proposta que fiz no campo da alfabetização de adultos, há alguns anos passados. Proposta que me levou... 
Inicialmente me parece interessante reafirmar que sempre vi a alfabetização de adultos como um ato político e um ato de conhecimento, por isso, como um ato criador. Para mim seria impossível engajar-me num trabalho de memorização mecânica dos ba-be-bi-bo-bu, dos la-le-li-lo-lu. Daí que também não pudesse reduzir a alfabetização ao ensino puro da palavra, das sílabas ou das letras. Ensino em cujo processo o alfabetizador fosse "enchendo" com suas palavras as cabeças supostamente "vazias" dos alfabetizandos. Pelo contrário, enquanto ato de conhecimento e ato criador, o processo da alfabetização tem, no alfabetizando, o seu sujeito. $\mathrm{O}$ fato de ele necessitar da ajuda do educador, como ocorre em qualquer relação pedagógica, não significa dever a ajuda do educador anular a sua criatividade e a sua responsabilidade na construção de sua linguagem escrita e na leitura desta linguagem. Na verdade, tanto o alfabetizador quanto o alfabetizando, ao pegarem, por exemplo, um objeto, como faço agora com o que tenho entre os dedos, sentem o objeto, percebem o objeto sentido e são capazes de expressar verbalmente o objeto sentido e percebido. Como eu, o analfabeto é capaz de sentir a caneta, de perceber a caneta e de dizer caneta. Eu, porém, sou capaz de não apenas sentir a caneta, de perceber a caneta, de dizer caneta, mas também de escrever caneta e, consequentemente, de ler caneta. A alfabetização é a criação ou a montagem da expressão escrita da expressão oral do objeto sentido e percebido. Esta montagem não pode ser feita, porém, pelo educador para ou sobre o alfabetizando. Aí tem ele a sua grande tarefa criadora.

Creio desnecessário me alongar mais, aqui e agora, sobre o que tenho desenvolvido, em diferentes momentos, em ensaios e textos, a propósito da complexidade deste processo. A um ponto, porém, referido várias vezes neste texto, gostaria de voltar, pela significação que tem para a compreensão crítica do ato de ler e, consequentemente, para a proposta de alfabetização a que me consagrei. Refiro-me a que a leitura do mundo precede sempre a leitura da palavra e a leitura desta implica na continuidade da leitura daquele. Na proposta a que me referi acima, este movimento do mundo à palavra e da palavra ao mundo está sempre presente. Movimento em que a palavra dita flui do mundo mesmo através da leitura que dele fazemos. De alguma maneira, porém, podemos ir mais longe e dizer que a leitura da palavra não é apenas precedida pela leitura do mundo, mas por uma certa forma de "escrevê-lo" ou de "reescrevê-lo", quer dizer, de transformá-lo através da prática consciente.

Este movimento dinâmico é um dos aspectos centrais, para mim, do processo de alfabetização. Daí que sempre tenha insistido em que as palavras com que organizar o programa da alfabetização deveriam vir do universo vocabular dos 
grupos populares, deveriam expressar a sua real linguagem, os seus anseios, as suas inquietações, as suas reivindicações, os seus sonhos. Deveriam vir carregadas da significação da sua experiência existencial e não da experiência do educador. A pesquisa do que chamava de universo vocabular nos dava assim as palavras do povo, grávidas de mundo. Elas nos vinham através da leitura do mundo que os grupos populares faziam. Depois, voltavam a eles, inseridas no que chamava e chamo de codificações, que são representações da realidade.

A palavra "tijolo", por exemplo, se inseriria numa representação pictórica, a de um grupo de pedreiros, construindo uma casa. Mas, antes da devolução, em forma escrita, da palavra oral dos grupos populares, a eles, para o processo de sua apreensão e não de sua memorização mecânica, costumávamos desafiar os alfabetizandos com um conjunto de situações codificadas de cuja descodificação ou "leitura" resultava a percepção crítica do que é cultura, pela compreensão da prática ou do trabalho humano, transformador do mundo. No fundo, esse conjunto de representações de situações concretas possibilitava aos grupos populares uma "leitura" da "leitura" anterior do mundo, antes da leitura palavra. Que horas são agora? Na alfabetização que se seguia, continuava a leitura do mundo pela leitura da palavra.

Esta "leitura" mais crítica da "leitura" anterior menos crítica do mundo possibilitava aos grupos populares, às vezes em posição fatalista em face das injustiças, uma compreensão diferente da sua indigência.

É neste sentido que a leitura crítica da realidade, dando-se num processo de alfabetização e associada sobretudo a certas práticas claramente políticas de mobilização e de organização, pode constituir-se num instrumento para o que Gramsci chamaria de ação contra hegemônica.

Concluindo estas reflexões em torno da importância do ato de ler, que implica sempre em percepção crítica, em interpretação e em "reescrita" do lido, gostaria de dizer que, depois de hesitar um pouco, resolvi adotar o procedimento que usei no tratamento do tema, em consonância com a minha forma de ser e com o que posso fazer.

Finalmente, quero felicitar os organizadores e os idealizadores deste Congresso. Nunca, possivelmente, temos necessitado tanto de encontros como este, como agora. Muito obrigado.

Ezequiel Theodoro da Silva: - A Comissão Organizadora gostaria de agradecer ao professor Paulo Freire por essas palavras maravilhosas e alguém aqui da Secretaria Municipal de Cultura me disse que há três anos atrás, quando realizamos o primeiro 
Memória sonora: A importância do ato de ler

Congresso de Leitura, nós fizemos uma mesa redonda sobre o método Paulo Freire. Naquela época, a gente não tinha o Paulo Freire aqui no Brasil...

Paulo Freire: - Foi um ato de bravura.

Ezequiel Theodoro da Silva: -É, um ato de bravura. Mas hoje a gente está repetindo com o Paulo Freire em pessoa. Paulo, muito obrigado.

Paulo Freire em Campinas, no $3^{\circ}$ COLE, 13 de novembro de 1981.

\section{REFERÊNCIAS}

FREIRE, Paulo. A importância do ato de ler: em três artigos que se completam. 26. ed. Prefácio de Antonio Joaquim Severino. São Paulo: Cortez/Autores Associados, 1982. (Coleção Polêmicas do nosso Tempo)

FREIRE, Paulo. A importância do ato de ler. In: CONGRESSO DE LEITURA DO BRASIL. Resumos $3^{\circ}$ Congresso de Leitura do Brasil. Campinas, SP: FE/Unicamp. 1981. p. 3-6. Disponível em: https://issuu.com/pesquisaalbmemorias/docs/3 cole_-_resumos. Acesso em: 25 ago. 2021. 